\title{
Effects of yeast culture supplementation on lactation performance and rumen fermentation profile and microbial abundance in mid-lactation Holstein dairy cows
}

\author{
J. Halfen, ${ }^{1,2} \odot$ N. Carpinelli, ${ }^{1} \odot$ F. A. B. Del Pino, ${ }^{2} \odot$ J. D. Chapman, ${ }^{3} \odot$ E. D. Sharman, ${ }^{3} \odot$ J. L. Anderson, ${ }^{1} \odot$ \\ and J. S. Osorio ${ }^{1 *}$ (1) \\ ${ }^{1}$ Department of Dairy and Food Sciences, South Dakota State University, Brookings, SD 57007 \\ ${ }^{2}$ Núcleo de Ensino, Pesquisa e Extensão em Pecuaria (NUPEEC), Departamento de Clínica Veterinaria, \\ Programa de Pós-Graduação em Zootecnia, Universidade Federal de Pelotas, 96160-000 Pelotas, RS, Brazil \\ ${ }^{3}$ Phibro Animal Health Corporation, Teaneck, NJ 07666
}

\begin{abstract}
The continuous trend for a narrowing margin between feed cost and milk prices across dairy farms in the United States highlights the need to improve and maintain feed efficiency. Yeast culture products are alternative supplements that have been evaluated in terms of milk performance and feed efficiency; however, less is known about their potential effects on altering rumen microbial populations and consequently rumen fermentation. Therefore, the objective of this study was to evaluate the effect of yeast culture supplementation on lactation performance, rumen fermentation profile, and abundance of major species of ruminal bacteria in lactating dairy cows. Forty mid-lactation Holstein dairy cows (121 \pm 43 days in milk; mean \pm standard deviation; 32 multiparous and 8 primiparous) were used in a randomized complete block design with a 7-d adaptation period followed by a $60-\mathrm{d}$ treatment period. Cows were blocked by parity, days in milk, and previous lactation milk yield and assigned to a basal total mixed ration (TMR; $1.6 \mathrm{Mcal} / \mathrm{kg}$ of dry matter, $14.6 \%$ crude protein, $21.5 \%$ starch, and $38.4 \%$ neutral detergent fiber) plus $114 \mathrm{~g} / \mathrm{d}$ of ground corn $(\mathrm{CON} ; \mathrm{n}=20)$ or basal TMR plus $100 \mathrm{~g} / \mathrm{d}$ of ground corn and $14 \mathrm{~g} / \mathrm{d}$ of yeast culture (YC; $\mathrm{n}=20$; Culture Classic HD, Cellerate Yeast Solutions, Phibro Animal Health Corp.). Treatments were top-dressed over the TMR once a day. Cows were individually fed $1 \times / d$ throughout the trial. Blood and rumen fluid samples were collected in a subset of cows ( $\mathrm{n}=10 /$ treatment $)$ at 0,30 , and $60 \mathrm{~d}$ of the treatment period. Rumen fluid sampled via esophageal tubing was analyzed for ammonia-N, volatile fatty acids (VFA), and ruminal bacteria populations via quantita-
\end{abstract}

Received December 6, 2020.

Accepted July 8, 2021.

*Corresponding author: Johan.Osorio@sdstate.edu tive PCR amplification of $16 \mathrm{~S}$ ribosomal DNA genes. Milk yield was not affected by treatment effects. Energy balance was lower in YC cows than CON, which was partially explain by the trend for lower dry matter intake as \% body weight in YC cows than CON. Cows fed YC had greater overall ruminal $\mathrm{pH}$ and greater total VFA $(\mathrm{mM})$ at $60 \mathrm{~d}$ of treatment period. There was a contrasting greater molar proportion of isovalerate and lower acetate proportion in YC-fed cows compared with CON cows. Although the ruminal abundance of specific fiber-digesting bacteria, including Eubacterium ruminantium and Ruminococcus flavefaciens, was increased in YC cows, others such as Fibrobacter succinogenes were decreased. The abundance of amylolytic bacteria such as Ruminobacter amylophilus and Succinimonas amylolytica were decreased in YC cows than CON. Our results indicate that the yeast culture supplementation seems to promote some specific fiber-digesting bacteria while decreasing amylolytic bacteria, which might have partially promoted more neutral rumen $\mathrm{pH}$, greater total VFA, and isovalerate.

Key words: yeast culture, rumen bacteria, feed efficiency

\section{INTRODUCTION}

Over the last decades, the focus of the dairy industry has been to maximize milk yield. This has been partially accomplished via intensive genetic selection and feeding strategies to improve feed efficiency and milk production. Feeding Saccharomyces cerevisiae yeast-based products has been reported to improve milk production (Leicester et al., 2016; Acharya et al., 2017; Dias et al., 2018a) and feed efficiency (Poppy et al., 2012; Dias et al., 2018b), while stabilizing rumen $\mathrm{pH}$ and promote a constant environment for rumen fermentation (Bach et al., 2007; Chaucheyras-Durand et al., 2008; Dias et al., 2018a). 
Commercial yeast products and yeast-containing feed ingredients vary on many characteristics, including yeast strain, viability (i.e., active dry yeast or dead yeast), yeast culture and media associated with it, and postfermentation processing (e.g., fractionated yeast; Shurson, 2018). Yeast culture is unique among yeast products because it comprises yeast biomass and fermentation metabolites (Shurson, 2018). The composition and characteristics of fermentation metabolites are highly dependent on the medium used to grow the yeast. Yeast culture is dried in a manner to preserve the fermenting activity of the yeast and may contain small to negligible residual amounts of viable yeast cells (Shurson, 2018; AAFCO, 2020). The benefits of yeast culture have been attributed to the presence of functional metabolites (e.g., organic acids, B vitamins, AA, and enzymes) that may influence ruminal fermentation by supplying key nutrients otherwise scarce in the ruminal environment (Oeztuerk, 2009; Opsi et al., 2012). At the rumen level, yeast culture seems to exert beneficial effects, preventing SARA and improving feed efficiency in dairy cows (Dias et al., 2018b). These effects have been partially explained by yeast culture's ability to alter ruminal fermentation by stimulating growth and activity of fiber-digesting and lactate-utilizing bacteria (Zhu et al., 2017).

The abundance of various rumen bacterial taxa has been correlated with feed efficiency and animal performance, indicating that the bacterial community plays an important role in regulating host physiological parameters (Jami et al., 2014; Shabat et al., 2016). At the rumen level, yeast culture seems to exert beneficial effects, stabilizing ruminal $\mathrm{pH}$ and improving feed efficiency in dairy cows (Dias et al., 2018b). These effects have been partially explained by yeast culture's ability to alter ruminal fermentation by stimulating growth and activity of cellulolytic (Fibrobacter and Ruminococcus species) and lactate-utilizing bacteria (Megasphaera and Selenomonas species; Newbold et al., 1995; Callaway and Martin, 1997; Zhu et al., 2017). Recently, Tun et al. (2020) evaluated the effect of yeast culture supplementation both in vivo and in vitro, and their results suggested that yeast culture protected the rumen microbial diversity from the negative effect of a low rumen $\mathrm{pH}$. These authors also reported that yeast culture promoted the growth of cellulolytic and lactateutilizing bacteria in both trials. Lactate-utilizing bacteria have been linked with enhanced animal efficiency due to their involvement in channeling the metabolic pathway that converts lactate into propionate (Shabat et al., 2016).

Although several studies on yeast culture products in lactating dairy cows have evaluated its effect on fermentation parameters (Hristov et al., 2010; Zhu et al., 2017; Dias et al., 2018a), only a few studies performed in lactating dairy cows have evaluated yeast culture effect in ruminal bacteria abundance, which to our knowledge were Mullins et al. (2013), Zhu et al. (2017), and Tun et al. (2020). The latter suggests that the responses to yeast culture supplementation in lactating dairy cows on ruminal microbiology remain to be elucidated, as do its associations with animal performance. We hypothesized that feeding a yeast culture product derived from a Saccharomyces cerevisiae containing yeast, yeast components, and fermentation metabolites will improve the ruminal environment and modify rumen fermentation through increased ruminal cellulolytic and lactate-utilizer bacteria. The objective of the study was to evaluate the effects of feeding yeast culture on mid-lactation performance, rumen fermentation characteristics, and rumen bacterial populations in lactating dairy cows.

\section{MATERIALS AND METHODS}

\section{Animal Housing and Care}

All the procedures for this study were conducted in accordance with the protocol approved by the Institutional Animal Care and Use Committee at the South Dakota State University (Protocol no. 18-028A). The experiment was conducted from December 2018 to May 2019. Weather data from Mesonet at South Dakota State University (https://climate.sdstate.edu/) was used to evaluate the average daily temperature during the experimental period, which was $-2.65 \pm$ $6.06^{\circ} \mathrm{C}$. Cows were housed in a ventilated enclosed barn with access to mattress freestalls and fed once daily at $0630 \mathrm{~h}$ using individual electronic admission gates with respective transponders (American Calan). Individual orts were collected once a day before feeding to determine feed intake. Feed offered was adjusted daily to achieve 5 to $10 \%$ refusal.

\section{Design and Treatment Diets}

Forty mid-lactation Holstein dairy cows (124 \pm 42 DIM; mean \pm SD), including 32 multiparous and 8 primiparous cows, were used in a randomized complete block design with a 7-d covariate period followed by a 60-d treatment period. Cows were blocked by lactation number, DIM, and milk production during the last $4 \mathrm{~d}$ of the adaptation period and randomly assigned to 1 of 2 treatments ( $\mathrm{n}=20$ per treatment). Cows received the same basal diet as a TMR (Table 1) supplemented with $114 \mathrm{~g} / \mathrm{d}$ of ground corn as a control group $(\mathbf{C O N})$ or 14 $\mathrm{g} / \mathrm{d}$ of yeast culture (YC; Culture Classic HD, Cellerate Yeast Solutions, Phibro Animal Health Corp.) blended 
with $100 \mathrm{~g} / \mathrm{d}$ of ground corn, as a treatment group. The treatment products were top-dressed individually over the TMR within $1 \mathrm{~h}$ after morning feeding. According to AAFCO definitions (AAFCO, 2020), the product used is a yeast culture, which contains yeast biomass and fermentation metabolites originating from Saccharomyces cerevisiae grown on a medium and dried on beneficial plant-based carriers. Cows in the YC group were fed the $\mathrm{CON}$ treatment during the covariate period. Diets were formulated using the CNCPS model (v. 6.55; Van Amburgh et al., 2015) contained in the NDS Professional ration formulation software (v. 6.55; RUM\&N, NDS Professional).

Table 1. Ingredient and chemical composition of basal diet fed during the experiment period for all groups

\begin{tabular}{|c|c|}
\hline Item & Basal diet \\
\hline \multicolumn{2}{|l|}{ Ingredient, $\%$ of $\mathrm{DM}^{1}$} \\
\hline Alfalfa hay & 10.1 \\
\hline Alfalfa silage & 10.1 \\
\hline Corn silage & 38.4 \\
\hline Whole cottonseed with lint & 7.6 \\
\hline Corn grain ground fine & 17.7 \\
\hline Soybean meal & 4.0 \\
\hline Wheat middling & 4.0 \\
\hline Rumen-inert fat ${ }^{2}$ & 1.0 \\
\hline Urea & 0.12 \\
\hline Distillers grain dry & 4.0 \\
\hline Calcium carbonate & 1.1 \\
\hline Sodium bicarbonate & 1.0 \\
\hline Salt white & 0.38 \\
\hline Magnesium oxide & 0.18 \\
\hline Vitamin $E^{3}$ & 0.04 \\
\hline Monensin $^{4}$ & 0.01 \\
\hline Biotin $1 \%$ & 0.01 \\
\hline Rumen-protected Met $^{5}$ & 0.04 \\
\hline Vitamin premix $^{6}$ & 0.11 \\
\hline Trace mineral premix ${ }^{7}$ & 0.11 \\
\hline \multicolumn{2}{|l|}{ Chemical analysis } \\
\hline $\mathrm{NEL}, \mathrm{Mcal} / \mathrm{kg}$ of $\mathrm{DM} \pm \mathrm{SD}$ & $1.6 \pm 0.03$ \\
\hline $\mathrm{CP}, \%$ of DM & $14.6 \pm 0.5$ \\
\hline $\mathrm{ADF}, \%$ of $\mathrm{DM}$ & $24.3 \pm 1.8$ \\
\hline $\mathrm{NDF}, \%$ of DM & $38.4 \pm 1.2$ \\
\hline $\mathrm{NFC}, \%$ of $\mathrm{DM}$ & $33.0 \pm 2.0$ \\
\hline Starch, \% of DM & $21.5 \pm 1.6$ \\
\hline Crude fat, $\%$ of DM & $5.1 \pm 0.7$ \\
\hline
\end{tabular}

${ }^{1}$ Ingredients included in the ration formulated by using NDS Professional based on CNCPS (Nutrition Dynamic System; RUM\&N Sas.).

${ }^{2}$ Energy Booster 100 (MSC).

${ }^{3}$ Vitamin E, 9,090 IU $/ \mathrm{kg}$.

${ }^{4}$ Rumensin 90 (200 g of monensin in $1 \mathrm{~kg}$ of product).

${ }^{5}$ Mepron (Evonik nutrition and care $\mathrm{GmbH}$ ).

${ }^{6} \mathrm{JPW}$ dairy vitamin premix: $28.10 \% \mathrm{Ca}$ (DM basis) $2,500 \mathrm{IU} / \mathrm{kg}$ of vitamin $\mathrm{A}, 834 \mathrm{IU} / \mathrm{kg}$ of vitamin $\mathrm{D}$, and $8,334 \mathrm{IU} / \mathrm{kg}$ of vitamin $\mathrm{E}$ (JPW Nutrition).

${ }^{7} \mathrm{JPW}$ dairy TM premix: $10.51 \% \mathrm{Ca}$ (DM basis), 3.70\% S, 10,417 mg/ $\mathrm{kg}$ of $\mathrm{Fe}, 62,500 \mathrm{mg} / \mathrm{kg}$ of $\mathrm{Zn}, 10,417 \mathrm{mg} / \mathrm{kg}$ of $\mathrm{Cu}, 52,084 \mathrm{mg} / \mathrm{kg}$ of $\mathrm{Mn}, 321 \mathrm{mg} / \mathrm{kg}$ of Se, $625 \mathrm{mg} / \mathrm{kg}$ of Co, and $1,042 \mathrm{mg} / \mathrm{kg}$ of I (JPW Nutrition).

\section{Data and Sample Collection}

Individual BW was recorded weekly during the adaptation and treatment periods. Body condition was scored weekly by 2 trained investigators on a 5 -point scale (Wildman et al., 1982). The DM of each diet ingredient was determined weekly, and the TMR was adjusted weekly to maintain the same diet formulation on a DM basis. Individual samples of diet ingredients and TMR were collected weekly and stored at $-20^{\circ} \mathrm{C}$ until analyzed. Samples were analyzed for DM, CP, NDF, ADF, starch, and crude fat using wet chemistry methods, whereas $\mathrm{NE}_{\mathrm{L}}$ and $\mathrm{NFC}$ were estimated by a commercial laboratory (Dairy One, Ithaca, NY).

Cows were milked twice a day, and the milk yield was recorded at each milking during the adaptation and experimental periods. Consecutive morning and evening milk samples were collected $1 \mathrm{~d} /$ wk during the experimental period. Composite milk samples were performed in proportion to milk yield at each milking, preserved with Bronopol and Natamycin (Broad Spectrum Microtabs II, Advanced Instruments), and analyzed for fat, protein, lactose, solids, MUN, and SCC using Fourier-transform infrared spectroscopy technology (Dairy One). The ECM was calculated based on milk yield and milk sample analysis as follows: $\mathrm{ECM}=[12.82 \times$ fat yield $(\mathrm{kg})]+[7.13 \times$ protein yield $(\mathrm{kg})]+[0.323 \times$ milk yield (kg)] (Tyrrell and Reid, 1965).

The energy balance (EB) for each cow was calculated based on equations from the (NRC, 2001). The net energy intake $\left(\mathbf{N E}_{\mathbf{I}}\right)$ was determined using daily $\mathrm{DMI} \times \mathrm{NE}_{\mathrm{L}}$ of the diet. The $\mathrm{NE}_{\mathrm{L}}$ was calculated from the TDN of the diet as $\mathrm{NE}_{\mathrm{L}}(\mathrm{Mcal} / \mathrm{kg})=0.0245 \times$ TDN $(\%)-0.12$. The $\mathrm{NE}_{\mathrm{M}}$ was calculated as $\mathrm{BW}^{0.75} \times$ 0.080. Requirements of $\mathrm{NE}_{\mathrm{L}}$ for milk production were calculated as $\mathrm{NE}_{\text {MILK }}=(0.0929 \times$ fat $\%+0.0547 \times$ protein $\%+0.0395 \times$ lactose $\%) \times$ milk yield. The equation used to calculate $\mathrm{EB}(\mathrm{Mcal} / \mathrm{d})$ was $\mathrm{EB}=$ $\mathrm{NE}_{\mathrm{I}-}\left(\mathrm{NE}_{\mathrm{M}}+\mathrm{NE}_{\mathrm{MILK}}\right)$ and $\mathrm{EB}$ (as \% of requirements) $=\left[\mathrm{NE}_{\mathrm{I}} /\left(\mathrm{NE}_{\mathrm{M}}+\mathrm{NE}_{\mathrm{MILK}}\right)\right] \times 100$.

Rumen fluid was collected from 20 cows $(\mathrm{n}=10$ per treatment; 16 multiparous and 4 primiparous cows) during the last day of adaptation $(0 \mathrm{~d})$ and at 30 and $60 \mathrm{~d}$ of supplementation. Cows were sampled in the afternoon via esophageal tube $3 \mathrm{~h}$ after morning feeding. The esophageal tubing apparatus was assembled by coupling the esophageal tube to a metal strainer (Raun and Burroughs, 1962) on one end, and the other end connected to the opposite handle side of a manual vacuum pump (Med-Eze stomach pump, MAI Animal Health). The rumen fluid sample was collected by passing the fluid through the pump's hollow shaft and into a plastic beaker. After discarding the first $200 \mathrm{~mL}$ of 
fluid to minimize saliva contamination, approximately $50 \mathrm{~mL}$ of rumen fluid was collected. After collection, the $\mathrm{pH}$ was immediately measured using a $\mathrm{pH}$ meter (Waterproof $\mathrm{pH}$ Testr 30, Oakton Instruments), and 2 aliquots $(10 \mathrm{~mL})$ were acidified with either $200 \mu \mathrm{L}$ of $50 \%$ sulfuric acid or $2 \mathrm{~mL}$ of $25 \%$ meta-phosphoric acid and stored at $-20^{\circ} \mathrm{C}$ until analysis of ammonia- $\mathrm{N}$ $\left(\mathrm{NH}_{3}-\mathrm{N}\right)$ and VFA, respectively. In addition, a 2-mL rumen fluid sample was collected and immediately frozen in liquid nitrogen and stored at $-80^{\circ} \mathrm{C}$ until DNA isolation and subsequent relative abundance of bacteria species was performed via quantitative PCR (qPCR) method.

Rumen fluid samples preserved with sulfuric acid and $25 \%$ meta-phosphoric acid were thawed and transferred into 2-mL microcentrifuge tubes. Then, samples were centrifuged at $30,000 \times g$ for $20 \mathrm{~min}$ at $4^{\circ} \mathrm{C}$ (model 5403, Eppendorf), and the supernatant from samples in sulfuric acid was used to analyzed $\mathrm{NH}_{3}-\mathrm{N}$ using a colorimetric assay described by Chaney and Marbach (1962). The supernatant of rumen fluid containing $25 \%$ meta-phosphoric acid was analyzed for acetate, propionate, butyrate, isobutyrate, isovalerate, and valerate concentrations using an automated gas chromatograph (model 689, Hewlett-Packard) equipped with a 0.25 mm i.d $\times 15-m$ column (Nukol 24106-U, Supelco, Inc.) and the internal standard used was 2-ethylbutyrate.

\section{Ruminal Bacteria DNA Isolation and qPCR Amplification of $16 S$ rDNA Genes}

Ruminal bacteria DNA was isolated using the QIAamp Fast DNA Stool mini kit (Qiagen) with modifications to the protocol described by Henderson et al. (2013). Briefly, $1 \mathrm{~mL}$ of rumen fluid was centrifuged at 12,000 $\times g$ for $5 \mathrm{~min}$ at room temperature $\left(20-25^{\circ} \mathrm{C}\right)$, and the supernatant was discarded. Pellet was resuspended in $1 \mathrm{~mL}$ of buffer EX, vortexed, incubated in a heat block at $95^{\circ} \mathrm{C}$ for $5 \mathrm{~min}$, and centrifuged at $20,000 \times g$ for 1 $\mathrm{min}$ at room temperature $\left(20-25^{\circ} \mathrm{C}\right)$. Then, $600 \mu \mathrm{L}$ of supernatant was transferred to a new microcentrifuge tube contained $25 \mu \mathrm{L}$ of Qiagen proteinase $\mathrm{K}$, followed by the addition of $600 \mu \mathrm{L}$ of Buffer AL. The mixture was vortexed for $15 \mathrm{~s}$ and incubated at $70^{\circ} \mathrm{C}$ for $10 \mathrm{~min}$. After incubation, $600 \mu \mathrm{L}$ of $96 \%$ molecular ethanol was added and vortexed. The mixture was transferred into a QIAamp mini spin column, and the subsequent steps were performed according to manufacturer's procedures (Qiagen). The quantity and purity were measured using a NanoDrop spectrophotometer (ND 1000, NanoDrop Technologies Inc.). The extracted DNA was standardized to $8 \mathrm{ng} / \mu \mathrm{L}$ for $\mathrm{qPCR}$.

The primer sets used in this study to evaluate the relative abundance of 18 bacterial species have been previously reported and validated (Supplemental Table S1, https://doi.org/10.6084/m9.figshare.15145071.v1; Halfen et al., 2021). The quantitative PCR analysis was performed using $10 \mu \mathrm{L}$ of qPCR mixture containing 4 $\mu \mathrm{L}$ of DNA sample, $5 \mu \mathrm{L}$ of $1 \times$ SYBR Green master mix (Applied Biosystems), $0.4 \mu \mathrm{L}$ of each forward and reverse primers, and $0.2 \mu \mathrm{L}$ of DNase-RNase-free water in a MicroAmp Optical 384-well reaction plate (Applied Biosystems). Each sample was run in triplicate, and the relative abundance was determined based on a 6-point standard curve plus a no-template control. The 4-fold-dilution standard curve was created using standardized DNA from all samples. The qPCR reactions were performed with the QuantStudio 6 Flex Real-Time PCR System (Applied Biosystems) using the same conditions described by Grazziotin et al. (2020). A geometrical mean of 2 universal primers was used to calculate the relative abundance of bacterial species with the efficiency-corrected $\Delta$-CT method (Abdelmegeid et al., 2018). The relative abundance of each bacterial species is relative to the total bacteria abundance measured with these universal primers.

\section{Blood Biomarker Analyses}

Blood samples were collected from 20 cows $(n=10$ per treatment; 16 multiparous and 4 primiparous cows) via coccygeal vein before morning feeding at 0,30 , and $60 \mathrm{~d}$ of supplementation. Samples were collected into evacuated serum tubes (BD Vacutainer, Becton Dickinson) containing either clot activator or lithium heparin for serum or plasma, respectively. After blood collection, tubes with lithium heparin were placed on ice, and tubes with clot activator were kept at $21^{\circ} \mathrm{C}$ until centrifugation ( $\sim 30 \mathrm{~min})$. Serum and plasma were obtained by centrifugation at $1,300 \times g$ for $15 \mathrm{~min}$ at $21^{\circ} \mathrm{C}$ and $4^{\circ} \mathrm{C}$, respectively. Aliquots of serum and plasma were frozen $\left(-80^{\circ} \mathrm{C}\right)$ until further analysis. Samples were analyzed for nonesterified fatty acids (NEFA; catalog no. 99934691, Wako Chemicals Inc.) and BHB (catalog no. H7587-58, Pointe Scientific Inc.) using kits in an autoanalyzer (Vet AXCEL, Alfa Wassermann) at the Animal Disease Research and Diagnostic Laboratory at South Dakota State University. Glucose concentration was measured using a commercial kit (catalog no. 99703001, Wako Chemicals Inc.). The concentration of BUN was determined using diacetylmonoxime (catalog no. 0580250, Stanbio Laboratory)

\section{Statistical Analysis}

Data were analyzed as repeated measures with the MIXED procedure of SAS version 9.4 (SAS Institute Inc.) using treatment, time (day or week), parity, and 
Table 2. Effects of supplementing a yeast culture product (YC) on BW, BCS, DMI, DMI (\% of BW), and energy balance parameters in mid-lactation dairy cows

\begin{tabular}{|c|c|c|c|c|c|c|}
\hline \multirow[b]{2}{*}{ Item } & \multicolumn{2}{|c|}{ Treatment $^{1}$} & \multirow[b]{2}{*}{$\mathrm{SEM}^{2}$} & \multicolumn{3}{|c|}{$P$-value ${ }^{3}$} \\
\hline & $\mathrm{CON}$ & $\mathrm{YC}$ & & Trt & Time & $\operatorname{Trt} \times \mathrm{T}^{4}$ \\
\hline $\begin{array}{l}\text { BW, } \mathrm{kg} \\
\mathrm{BCS}^{5} \\
\mathrm{ADG}, \mathrm{kg} / \mathrm{d} \\
\mathrm{DMI}, \mathrm{kg} / \mathrm{d} \\
\text { DMI, \% of BW } \\
\text { Energy balance, } \mathrm{Mcal} / \mathrm{d} \\
\text { Energy balance, }{ }^{6} \%\end{array}$ & $\begin{array}{r}718 \\
2.85 \\
0.51 \\
26.03 \\
3.68 \\
6.64 \\
118.6\end{array}$ & $\begin{array}{r}722 \\
2.88 \\
0.40 \\
25.51 \\
3.49 \\
3.74 \\
110.0\end{array}$ & $\begin{array}{l}4.40 \\
0.03 \\
0.21 \\
0.78 \\
0.11 \\
0.99 \\
3.21\end{array}$ & $\begin{array}{l}0.57 \\
0.58 \\
0.62 \\
0.55 \\
0.07 \\
0.02 \\
0.03\end{array}$ & $\begin{array}{r}<0.01 \\
0.02 \\
<0.01 \\
<0.01 \\
<0.01 \\
<0.01 \\
<0.01\end{array}$ & $\begin{array}{l}0.37 \\
0.48 \\
0.27 \\
0.96 \\
0.87 \\
0.77 \\
0.76\end{array}$ \\
\hline \multicolumn{7}{|c|}{$\begin{array}{l}{ }^{1} \text { Cows were assigned to a basal TMR }(1.6 \mathrm{Mcal} / \mathrm{kg} \text { of } \mathrm{DM}, 14.6 \% \mathrm{CP}, 21.5 \% \text { starch, and } 38.4 \% \mathrm{NDF}) \text { plus } 11 \\
\mathrm{~g} / \mathrm{d} \text { of ground corn }(\mathrm{CON} ; \mathrm{n}=20 \text { ) or basal TMR plus } 100 \mathrm{~g} / \mathrm{d} \text { of ground corn and } 14 \mathrm{~g} / \mathrm{d} \text { of yeast culture (YC } \\
\mathrm{n}=20 \text {; Culture Classic HD, Cellerate Yeast Solutions, Phibro Animal Health Corp.). } \\
{ }^{2} \text { Largest SEM. }\end{array}$} \\
\hline
\end{tabular}

2- and 3-way interactions with treatment as fixed effects and the random effects of cow and block. Interactions with parity were tested and removed from the model when $P>0.20$. Repeated measured data were modeled selecting the variance-covariance structures with least Bayesian information criterion value among compound symmetry, autoregressive $1[\mathrm{AR}(1)]$, or heterogeneous autoregressive $1[\mathrm{ARH}(1)]$. Covariate data collected during the adaptation period, including BW, BCS, DMI, milk yield, rumen parameters, and ruminal microbial populations as well as daily average temperature, were tested and removed from the model when $P>0.20$. The sample size for blood biomarkers and rumen fluid parameters $(\mathrm{n}=10$ per treatment) used in this study was based on prior studies on transition dairy cows evaluating ruminal bacteria population via PCR (Abdelmegeid et al., 2018; Elolimy et al., 2018b). However, the authors acknowledge that reducing the sample size from 20 to 10 animals per treatment cause a loss of statistical power. This subsampling was performed by randomly selecting half of the initial blocks of multiparous ( 8 blocks or 16 cows) and primiparous (2 blocks or 4 cows) cows. Statistical significance was considered at $P \leq 0.05$, and trends were declared at $0.05<P \leq 0.10$.

\section{RESULTS}

\section{Feed Intake, BW, ADG, BCS, and EB}

Main effects and interactions of BW, BCS, DMI, $\mathrm{DMI}$ as $\%$ of $\mathrm{BW}$, and $\mathrm{EB}$ parameters are presented in
Table 2. A treatment effect was observed for lower EB as Mcal/d $(P=0.02)$ and EB as $\%(P=0.03)$. A trend $(P=0.07)$ for lower DMI as \% of BW in YC cows than CON was observed. The BW, BCS, and DMI were not affected by treatment effects.

\section{Production Variables and Feed Efficiency}

Main effects and interactions for milk production variables and feed efficiency are presented in Table 3 . There was a treatment $($ Trt $) \times$ time interaction $(P=$ $0.03)$ in lactose $\%$, which was mainly associated with a trend $(P>0.08)$ for transient differences between treatments at 3 and $6 \mathrm{wk}$ of the experiment. There was a trend $(P=0.09)$ for greater feed efficiency as ECM/ DMI and milk/DMI in YC cows when compared with CON. Milk yield and components, MUN, SCC, and ECM, were not affected by treatment effects.

\section{Rumen Fermentation Parameters}

Main effects and interactions for rumen fermentation characteristics are presented in Table 4 . There was a Trt $\times$ time effect observed only for total VFA $(P=$ $0.05)$, which was attributed to greater $(P=0.03)$ total VFA in YC cows than CON at $60 \mathrm{~d}$ (Figure 1A). Greater $(P=0.02)$ ruminal $\mathrm{pH}$ was observed in $\mathrm{YC}$ cows in comparison to CON. There was a lower $(P$ $<0.01)$ acetate proportion in $\mathrm{YC}$ cows in comparison to CON. Similar to ruminal $\mathrm{pH}$, a greater $(P=0.01)$ isovalerate proportion was observed in $\mathrm{YC}$ cows than CON. 
Table 3. Effects of supplementing a yeast culture product (YC) on lactation performance and feed efficiency parameters in mid-lactation dairy cows

\begin{tabular}{|c|c|c|c|c|c|c|}
\hline \multirow[b]{2}{*}{ Item } & \multicolumn{2}{|c|}{ Treatment $^{1}$} & \multirow[b]{2}{*}{$\mathrm{SEM}^{2}$} & \multicolumn{3}{|c|}{$P$-value ${ }^{3}$} \\
\hline & $\mathrm{CON}$ & YC & & Trt & Trt $\times \mathrm{T}$ & Parity \\
\hline Milk yield, kg/d & 37.3 & 36.5 & 0.70 & 0.32 & 0.43 & 0.10 \\
\hline \multicolumn{7}{|l|}{ Milk composition } \\
\hline Fat, $\%$ & 3.88 & 3.90 & 0.11 & 0.88 & 0.86 & 0.35 \\
\hline Fat yield, $\mathrm{kg} / \mathrm{d}$ & 1.44 & 1.42 & 0.05 & 0.74 & 0.72 & 0.85 \\
\hline Protein, \% & 3.15 & 3.17 & 0.04 & 0.61 & 0.99 & 0.43 \\
\hline Protein yield, $\mathrm{kg} / \mathrm{d}$ & 1.17 & 1.16 & 0.03 & 0.77 & 0.59 & 0.22 \\
\hline Lactose, \% & 4.94 & 4.91 & 0.04 & 0.91 & 0.03 & 0.40 \\
\hline MUN, mg/dL & 9.66 & 9.24 & 0.38 & 0.35 & 0.89 & 0.33 \\
\hline Milk somatic cell linear score ${ }^{4}$ & 2.32 & 2.50 & 0.24 & 0.54 & 0.34 & 0.08 \\
\hline ECM, kg/d & 38.91 & 38.37 & 0.93 & 0.61 & 0.60 & 0.38 \\
\hline Milk/DMI & 1.43 & 1.48 & 0.03 & 0.09 & 0.72 & 0.01 \\
\hline ECM/DMI & 1.48 & 1.55 & 0.04 & 0.09 & 0.51 & 0.08 \\
\hline
\end{tabular}

${ }^{1}$ Cows were assigned to a basal TMR (1.6 Mcal $/ \mathrm{kg}$ of DM, $14.6 \% \mathrm{CP}, 21.5 \%$ starch, and $38.4 \% \mathrm{NDF}$ ) plus 114 $\mathrm{g} / \mathrm{d}$ of ground corn (CON; $\mathrm{n}=20$ ) or basal TMR plus $100 \mathrm{~g} / \mathrm{d}$ of ground corn and $14 \mathrm{~g} / \mathrm{d}$ of yeast culture (YC; $\mathrm{n}=20$; Culture Classic HD, Cellerate Yeast Solutions, Phibro Animal Health Corp.).

${ }^{2}$ Largest SEM.

${ }^{3} \mathrm{Trt} \times \mathrm{T}=$ interaction of treatment $\times$ time $($ week). None of the parameters had a parity $\times$ treatment effect $(P>0.20)$, and all parameters had a time effect at $P<0.01$.

${ }^{4}$ Somatic cell linear score $=\log _{2}(\mathrm{SCC} / 100)+3$.

\section{Abundance of Ruminal Bacteria}

Main effects and interactions for the relative abundance of selected bacterial species are presented in Table 5. Megasphaera elsdenii (Figure 1B) was the only bacteria with a Trt $\times$ time interaction $(P=0.05)$. This Trt $\times$ time was associated with a greater abundance of $M$. elsdenii in YC cows than CON at $30 \mathrm{~d}$. Greater abundance of Eubacterium ruminantium $(P=0.05)$ and Ruminococcus flavefaciens $(P=0.03)$ was observed in $\mathrm{YC}$ cows in comparison to CON. In contrast to $E$. ruminantium and $R$. flavefaciens, a lower abundance of Fibrobacter succinogenes $(P<0.01)$, Ruminobacter amylophilus $(P=0.05)$, Selenomonas ruminantium $(P$ $=0.02)$, and Succinimonas amylolytica $(P=0.04)$ was observed in $\mathrm{YC}$ cows in comparison to CON. A trend $(P=0.07)$ for a greater abundance of Prevotella bryantii was observed in YC cows than CON. Among all the bacteria species evaluated, only $F$. succinogenes had a parity $\times \operatorname{Trt}(P=0.03)$ interaction, which was mainly attributed to lower $(P<0.01)$ abundance of $F$. succinogenes in primiparous cows but not in multiparous cows (Supplemental Figure S1, https://doi.org/10.6084/m9 .figshare.15145071.v1; Halfen et al., 2021).

Table 4. Effects of supplementing a yeast culture product (YC) on ruminal fermentation characteristics in mid-lactation dairy cows

\begin{tabular}{|c|c|c|c|c|c|c|c|}
\hline \multirow[b]{2}{*}{ Rumen parameter } & \multicolumn{2}{|c|}{ Treatment $^{1}$} & \multirow[b]{2}{*}{$\mathrm{SEM}^{2}$} & \multicolumn{4}{|c|}{$P$-value } \\
\hline & $\mathrm{CON}$ & $\mathrm{YC}$ & & Trt & Time & $\operatorname{Trt} \times \mathrm{T}^{3}$ & Parity $^{4}$ \\
\hline $\mathrm{pH}$ & 5.86 & 6.03 & 0.05 & 0.02 & 0.02 & 0.82 & 0.05 \\
\hline $\mathrm{NH}_{3}, \mathrm{mg} / \mathrm{dL}$ & 6.68 & 6.75 & 1.40 & 0.96 & 0.58 & 0.50 & 0.12 \\
\hline $\begin{array}{l}\text { Total VFA, mM } \\
\text { VFA (mol/100 mol) }\end{array}$ & 88.5 & 90.6 & 3.8 & 0.65 & 0.04 & 0.05 & $<0.01$ \\
\hline Acetate & 61.1 & 59.6 & 0.62 & $<0.01$ & 0.98 & 0.19 & 0.49 \\
\hline Propionate & 26.6 & 27.5 & 0.90 & 0.39 & 0.62 & 0.59 & 0.61 \\
\hline Butyrate & 10.5 & 9.9 & 0.46 & 0.35 & 0.88 & 0.41 & 0.36 \\
\hline Isovalerate & 1.4 & 1.6 & 0.06 & 0.01 & 0.41 & 0.57 & 0.80 \\
\hline Valerate & 1.1 & 1.0 & 0.07 & 0.35 & $<0.01$ & 0.41 & 0.12 \\
\hline Acetate:Propionate & 2.21 & 2.09 & 0.15 & 0.34 & 0.55 & 0.63 & 0.15 \\
\hline
\end{tabular}

${ }^{1}$ Cows were assigned to a basal TMR (1.6 Mcal $/ \mathrm{kg}$ of DM, $14.6 \% \mathrm{CP}, 21.5 \%$ starch, and $38.4 \%$ NDF) plus 114 $\mathrm{g} / \mathrm{d}$ of ground corn (CON; $\mathrm{n}=20$ ) or basal TMR plus $100 \mathrm{~g} / \mathrm{d}$ of ground corn and $14 \mathrm{~g} / \mathrm{d}$ of yeast culture (YC; $\mathrm{n}=20$; Culture Classic HD, Cellerate Yeast Solutions, Phibro Animal Health Corp.).

${ }^{2}$ Largest SEM.

${ }^{3}$ Interaction of treatment $\times$ time (d 0, 30, and 60).

${ }^{4}$ None of the parameters had a parity $\times$ treatment effect $(P>0.20)$. 


\section{Blood Biomarkers}

Main effects and interactions for blood biomarkers results are presented in Table 6 . There was a Trt $\times$ time interaction in urea $(P<0.01)$ and NEFA $(P=$ $0.05)$. The Trt $\times$ time in urea was related to a lower $(P$ $<0.01)$ urea concentration in $\mathrm{YC}$ cows than $\mathrm{CON}$ at 60 $\mathrm{d}$ (Figure 2A). This was translated in an overall lower $(P<0.01)$ urea in $\mathrm{YC}$ cows than CON. The Trt $\times$ time in NEFA was associated with greater $(P<0.01)$ NEFA in $\mathrm{YC}$ cows than $\mathrm{CON}$ at $30 \mathrm{~d}$ (Figure $2 \mathrm{~B}$ ). There was a trend $(P=0.07)$ for greater BHB in YC-fed cows in comparison to CON. Blood glucose was not affected by treatment effects.

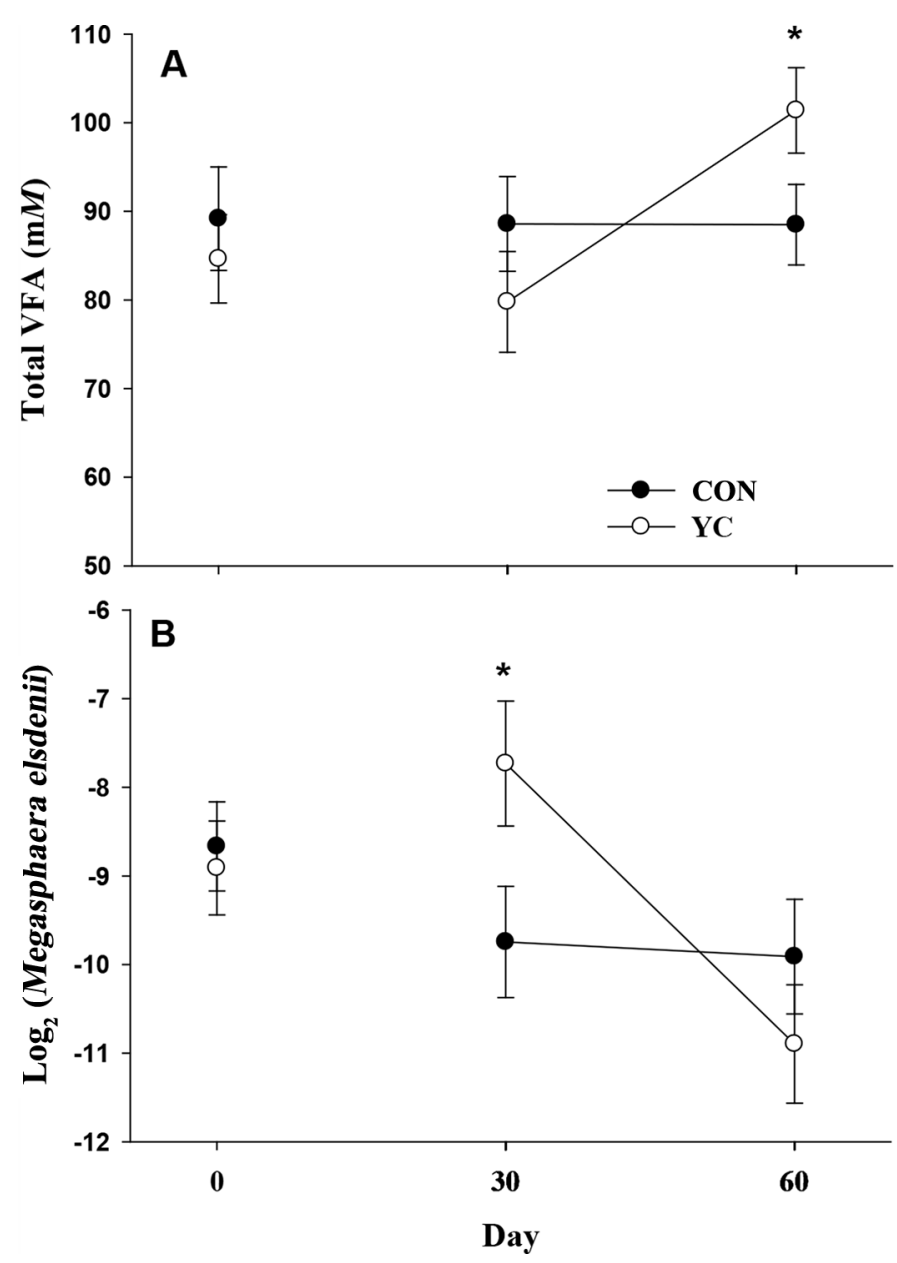

Figure 1. Ruminal parameters of total VFA (A) and Megasphaera elsdenii (B) in mid-lactation dairy cows fed a basal diet (CON) or a control diet supplemented with a yeast culture product (YC) during $60 \mathrm{~d}$ of the experimental period. Mean separations between treatments at a given time point were evaluated at a treatment $\times$ time interaction $(P \leq 0.10)$ and differences $(*)$ were declared at $P \leq 0.05$. Values are means, and SE are represented by vertical bars.

\section{DISCUSSION}

\section{Effects on DMI, BW, BCS, and EB}

A variety of performance parameters have been used to evaluate the potential benefits of supplementing yeast products in dairy cows' diets, with most studies focusing on DMI, milk yield, and the rumen environment (Poppy et al., 2012; Elghandour et al., 2020). Reductions in DMI have been reported in dairy cows supplemented with $S$. cerevisiae fermentation products. For instance, Shi et al. (2019) and Dias et al. (2018b) observed a decrease in DMI when early and late lactation dairy cows, respectively, were fed yeast culture products. Similarly, Alshaikh et al. (2002) observed lower DMI in mid-lactation dairy cows supplemented with 2 commercial sources of yeast culture. In contrast, others have reported a lack of response on feed intake in mid-lactation dairy cows supplemented with yeast culture (Zhu et al., 2017). Although no effects were observed in DMI as $\mathrm{kg} / \mathrm{d}$, a trend $(P=0.07)$ for a lower DMI as \% BW in YC was observed (Table 2). This lower DMI as \% BW can partially explain the lower EB observed in YC cow than CON. Similar to our results, Dias et al. (2018a) reported that cows supplemented with $15 \mathrm{~g} / \mathrm{d}$ of inactivated S. cerevisiae had lower EB than control cows, which was associated with increased energy requirements for milk production in yeast supplemented cows.

Dietary treatments did not affect BW or BCS in the current study (Table 2), which agrees with previous studies with live yeast (Ambriz-Vilchis et al., 2017; Ferreira et al., 2019) and yeast culture (Dias et al., 2018b). Yeast supplementation effects on BCS and BW are seldomly reported in adult dairy cows and seem to have a more consistent effect when supplemented to young ruminants (Alugongo et al., 2017).

\section{Production Variables and Feed Efficiency}

Several studies utilizing yeast culture products have shown inconsistent results in milk performance parameters. For instance, Poppy et al. (2012) performed a meta-analysis on 36 yeast culture supplementation studies and observed a positive effect on milk yield; however, yeast culture had the greatest influence on milk yield in early lactation. In a recent study in midlactation dairy cows, an increase of $3.3 \mathrm{~kg} / \mathrm{d}$ of milk yield was observed when cows were fed an inactivated dry S. cerevisiae yeast culture (Dias et al., 2018a). However, other authors did not observe effects on milk yield in mid (Schingoethe et al., 2004) and early lactation (Shi et al., 2019) dairy cows supplemented with yeast culture. Similar to those results reported in the litera- 
Table 5. Effects of supplementing a yeast culture product (YC) on relative abundance (\%) of microbial species in mixed ruminal fluid in midlactation dairy cows

\begin{tabular}{|c|c|c|c|c|c|c|c|}
\hline Species $^{1}$ & \multicolumn{2}{|c|}{ Treatment $^{2}$} & $\mathrm{SEM}^{3}$ & \multicolumn{4}{|c|}{$P$-value } \\
\hline Butyrivibrio fibrisolvens & $1.55 \times 10^{-3}$ & $1.51 \times 10^{-3}$ & 0.09 & 0.77 & 0.30 & 0.63 & 0.97 \\
\hline Butyrivibrio proteoclasticus & $8.62 \times 10^{-2}$ & $8.46 \times 10^{-2}$ & 0.24 & 0.92 & 0.84 & 0.21 & 0.72 \\
\hline Eubacterium ruminantium & $9.09 \times 10^{-3}$ & $1.36 \times 10^{-2}$ & 0.19 & 0.05 & 0.12 & 0.90 & 0.53 \\
\hline Fibrobacter succinogenes & $6.60 \times 10^{-2}$ & $4.18 \times 10^{-2}$ & 0.13 & $<0.01$ & 0.02 & 0.20 & 0.84 \\
\hline Prevotella bryantii & $7.86 \times 10^{-2}$ & $1.31 \times 10^{-1}$ & 0.32 & 0.07 & 0.97 & 0.74 & $<0.01$ \\
\hline Prevotella ruminicola & $1.10 \times 10^{0}$ & $9.49 \times 10^{-1}$ & 0.18 & 0.38 & $<0.01$ & 0.66 & 0.10 \\
\hline Prevotella brevis & $2.63 \times 10^{-1}$ & $2.19 \times 10^{-1}$ & 0.21 & 0.35 & 0.44 & 0.68 & 0.04 \\
\hline Ruminococcus albus & $1.04 \times 10^{-2}$ & $1.12 \times 10^{-2}$ & 0.26 & 0.74 & 0.29 & 0.98 & 0.89 \\
\hline Ruminococcus flavefaciens & $5.28 \times 10^{-4}$ & $8.79 \times 10^{-4}$ & 0.24 & 0.03 & 0.72 & 0.94 & 0.31 \\
\hline Ruminobacter amylophilus & $1.24 \times 10^{-3}$ & $7.12 \times 10^{-4}$ & 0.27 & 0.05 & $<0.01$ & 0.57 & 0.99 \\
\hline Selenomonas ruminantium & $3.30 \times 10^{-1}$ & $2.86 \times 10^{-1}$ & 0.06 & 0.02 & $<0.01$ & 0.92 & 0.58 \\
\hline
\end{tabular}

${ }^{1}$ Data were log-transformed before statistics. The SEM associated with log-transformed data are in log scale.

${ }^{2}$ Cows were assigned to a basal TMR $(1.6 \mathrm{Mcal} / \mathrm{kg}$ of DM, $14.6 \% \mathrm{CP}, 21.5 \%$ starch, and $38.4 \% \mathrm{NDF})$ plus $114 \mathrm{~g} / \mathrm{d}$ of ground corn $(\mathrm{CON}$; $\mathrm{n}=$ 20) or basal TMR plus $100 \mathrm{~g} / \mathrm{d}$ of ground corn and $14 \mathrm{~g} / \mathrm{d}$ of yeast culture (YC; $\mathrm{n}=20$; Culture Classic HD, Cellerate Yeast Solutions, Phibro Animal Health Corp.).

${ }^{3}$ Largest SEM is shown.

${ }^{4}$ Interaction of treatment $\times$ time $(\mathrm{d} 0,30$, and 60$)$.

${ }^{5}$ None of the parameters had a parity $\times$ treatment effect $(P>0.20)$. A parity $\times$ treatment $(P=0.03)$ was observed only in Fibrobacter succinogenes.

ture, YC supplementation in the current study did not cause any effect on milk yield adding to the contrasting effects of yeast culture supplementation on lactation performance.

Although ECM and milk yield did not differ between the treatments, YC cows tended $(P=0.09)$ to be more efficient in producing milk in terms of ECM/DMI and Milk/DMI ratios (Table 3). The increase in feed efficiency with no effects on milk yield has been reported previously in late (Dias et al., 2018b) and early (Shi et al., 2019) lactation dairy cows, whereas others demonstrated a trend for greater milk yield without differences on ECM and ECM/DMI (Zhu et al., 2017). Similar to the current study, Schingoethe et al. (2004) evaluated the effect of $60 \mathrm{~g} / \mathrm{d}$ yeast culture supplementation on mid-lactation dairy cows and observed no effect in either milk yield or ECM. However, a significant increase in feed efficiency as ECM/DMI was reported in cows

Table 6. Effects of supplementing a yeast culture product $(\mathrm{YC})$ on blood metabolites in mid-lactation dairy cows

\begin{tabular}{|c|c|c|c|c|c|c|}
\hline \multirow[b]{2}{*}{ Parameter } & \multicolumn{2}{|c|}{ Treatment $^{1}$} & \multirow[b]{2}{*}{$\mathrm{SEM}^{2}$} & \multicolumn{3}{|c|}{$P$-value ${ }^{3}$} \\
\hline & $\mathrm{CON}$ & $\mathrm{YC}$ & & Trt & Time & $\operatorname{Trt} \times \mathrm{T}^{4}$ \\
\hline Glucose, $\mathrm{mg} / \mathrm{dL}$ & 45.8 & 45.2 & 1.50 & 0.79 & 0.43 & 0.65 \\
\hline Urea, $\mu \mathrm{mol} / \mathrm{L}$ & 16.4 & 14.4 & 0.77 & 0.06 & 0.88 & 0.02 \\
\hline $\mathrm{NEFA}^{5}{ }^{5} \mathrm{mmol} / \mathrm{L}$ & 0.167 & 0.221 & 0.040 & 0.27 & 0.95 & 0.05 \\
\hline $\mathrm{BHB}, \mathrm{mmol} / \mathrm{L}$ & 0.207 & 0.266 & 0.038 & 0.07 & 0.42 & 0.25 \\
\hline
\end{tabular}

${ }^{1}$ Cows were assigned to a basal TMR (1.6 Mcal $/ \mathrm{kg}$ of DM, $14.6 \% \mathrm{CP}, 21.5 \%$ starch, and $\left.38.4 \% \mathrm{NDF}\right)$ plus 114 $\mathrm{g} / \mathrm{d}$ of ground corn $(\mathrm{CON} ; \mathrm{n}=20$ ) or basal TMR plus $100 \mathrm{~g} / \mathrm{d}$ of ground corn and $14 \mathrm{~g} / \mathrm{d}$ of yeast culture (YC; $\mathrm{n}=20$; Culture Classic HD, Cellerate Yeast Solutions, Phibro Animal Health Corp.).

${ }^{2}$ Largest SEM is shown.

${ }^{3}$ Parity was not significant $(P>0.44)$ in any of the parameters, and none had a parity $\times$ treatment $($ Trt) interaction $(P>0.20)$.

${ }^{4}$ Interaction of treatment $\times$ time $(\mathrm{d} 0,30$, and 60$)$.

${ }^{5} \mathrm{NEFA}=$ nonesterified fatty acids. 


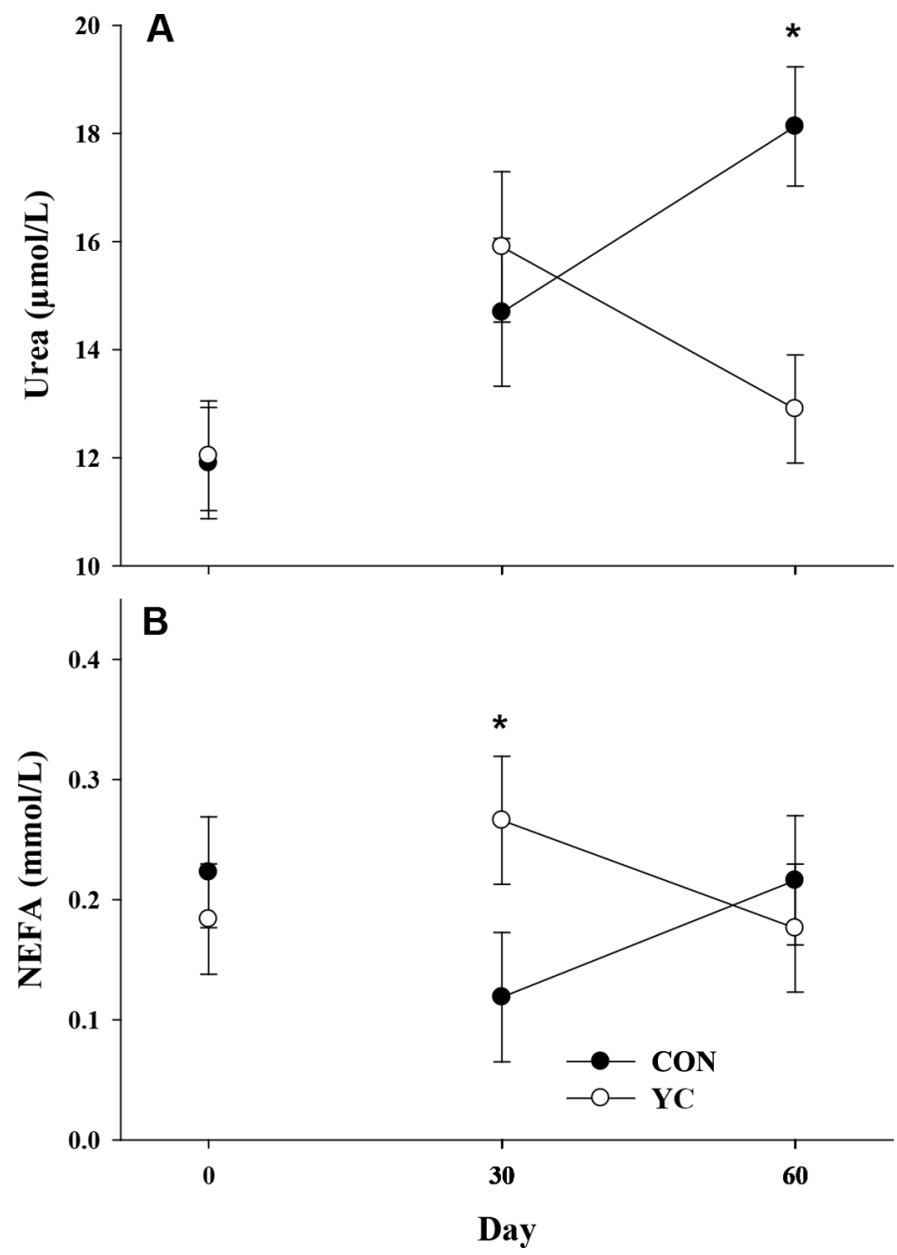

Figure 2. Blood urea (A) and nonesterified fatty acids (NEFA) (B) in mid-lactation dairy cows fed a basal diet (CON) or a control diet supplemented with a yeast culture product (YC) during $60 \mathrm{~d}$ of the experimental period. Mean separations between treatments at a given time point were evaluated at a treatment $\times$ time interaction $(P$ $\leq 0.10)$ and differences $(*)$ were declared at $P \leq 0.05$ and trend at $\bar{P} \leq 0.10$. Values are means, and $\mathrm{SE}$ are represented by vertical bars.

fed yeast culture. Dias et al. (2018b) showed an increase in feed efficiency in late lactation cows supplemented with $15 \mathrm{~g} / \mathrm{d}$ of inactivated yeast culture, attributed to lower DMI in yeast culture fed cows. The trend for improved feed efficiency observed in $\mathrm{YC}$ cows in the present study may be from the contribution of yeast metabolites present in the YC. Although the mechanisms of action of yeast culture have not been clearly established, its effects have been attributed to functional metabolites such as growth factors, B vitamins, AA, organic acids, enzymes, and other fermentation products (Ghazanfar et al., 2017; Elghandour et al., 2020). These metabolites are thought to influence ruminal fermentation by increasing VFA concentration and stimulating the growth of cellulolytic bacteria (Opsi et al., 2012; Zhu et al., 2017), improving DM digestibility
(Miller-Webster et al., 2002; Dias et al., 2018a) and consequently, feed efficiency.

\section{Blood Biomarkers}

In ruminants, the concentration of urea in blood and milk is highly correlated with $\mathrm{N}$ recycling and ruminal protein degradation due to the conversion of ruminal $\mathrm{NH}_{3}$ into urea in the liver (Colmenero and Broderick, 2006). The supplementation with yeast culture has been associated with a more efficient conversion of ruminal $\mathrm{NH}_{3}$ into microbial protein and decrease $\mathrm{NH}_{3}$ concentration in the rumen while reducing the $\mathrm{N}$ excretion as urinary urea or MUN (Hristov et al., 2010). In the present study, the ruminal $\mathrm{NH}_{3}$ was similar between groups (Table 4), and by the end of the experiment, YC cows had lower blood urea $\sim 13 \mu \mathrm{mol} / \mathrm{L}$, whereas CON cows had much higher levels $(\sim 18 \mu \mathrm{mol} / \mathrm{L})$, indicating a higher level of ureagenesis. This increase in urea in CON cows was not matched by an increase in MUN, suggesting that blood urea was either excreted in urine or recycled back to the rumen. Perhaps a more intensive evaluation of ruminal, metabolic, and milk parameters related to $\mathrm{N}$ recycling will confirm these potential effects of the yeast culture used in this study.

The greater NEFA in YC cows at $30 \mathrm{~d}$ (Figure 2B) coupled with the trend $(P=0.07)$ for greater BHB in $\mathrm{YC}$ cows than $\mathrm{CON}$ (Table 6) are in line with the lower EB in YC cows than CON (Table 2). However, although elevated NEFA and BHB are commonly associated with a lipolytic state due to low EB (Ospina et al., 2013), our data does not indicate cows were in a highly active lipolytic state but suggests that YC and $\mathrm{CON}$ cows have different metabolic demands as a result of the lower $\mathrm{EB}$ in $\mathrm{YC}$ cows.

\section{Rumen Fermentation Parameters}

Lactation diets are commonly formulated to contain greater amounts of starch in comparison to late lactation or dry cow diets to increase energy intake to support high milk production; however, this dietary condition can alter the normal microbial ecology in the rumen and increase the risk to develop digestive disorders, such as ruminal acidosis (Enemark, 2008; Abdela, 2016). In this context, there have been studies showing a lack of response of yeast culture supplementation on rumen pH (Hristov et al., 2010; Zhu et al., 2017). In contrast, others have observed an effect of yeast culture on maintaining rumen $\mathrm{pH}$, which has been attributed to a reduction in ruminal lactate production (Dias et al., 2018a) by stimulating the growth of lactate-utilizing bacteria such as M. elsdenii (Tun et al., 2020). A similar effect was observed in the present study, where 
YC-fed cows maintained a greater ruminal $\mathrm{pH}$ at 3 $\mathrm{h}$ postfeeding than CON (Table 4). When collecting rumen fluid taken at $4 \mathrm{~h}$ postfeeding via esophageal tubing, Plaizier (2004) used a threshold $\mathrm{pH}$ of 6.0 for SARA condition. Although differences in ruminal $\mathrm{pH}$ between CON and YC cows were small (5.86 vs. 6.03), the biological relevance of these data are underscored when compared with Plaizier (2004) SARA threshold $\mathrm{pH}$ of 6.0. Suggesting that cows in CON group were at a greater risk of developing SARA than YC cows.

It is important to note that there was a small inclusion rate of monensin, an ionophore with antimicrobial properties, in the basal diet in the present study (Table 1 ). This feed additive commonly leads to alterations in the ruminal parameters, including acetate and propionate (Bergen and Bates, 1984). However, according to Erasmus et al. (2005), no extent or complementary effects were observed between yeast culture and monensin by comparing their individual and combined effect on performance and ruminal parameters of dairy cows.

In the current study, cows fed $\mathrm{YC}$ had greater total VFA than CON at $60 \mathrm{~d}$ (Figure 1A), despite the lack of effect on total VFA indicated by other studies in mid-lactation dairy cows supplemented with yeast culture (Hristov et al., 2010; Li et al., 2016; Dias et al., 2018a). This greater total VFA has been attributed to improved stability of rumen fermentation due to yeast culture supplementation, coupled with an increase in rumen fiber-degrading bacteria (i.e., $R$. flavefaciens; Zhu et al., 2017). Similarly, Oeztuerk (2009) reported greater total VFA production during an in vitro trial with either live or autoclaved yeast. Therefore, the increase in total VFA in YC cows at $60 \mathrm{~d}$ can be partially ascribed to enhanced rumen benefits on increasing cellulolytic bacteria.

Yeast culture supplementation has been reported to alter not only total VFA but also the profile of VFA. For instance, Miller-Webster et al. (2002) reported greater propionate and lower acetate in a continuous culture study with yeast fermentation products. Similarly, a lower molar proportion of acetate was observed in YC cows (Table 4). Acharya et al. (2017) observed that cows fed different yeast culture products had greater propionate and lower acetate than control cows, whereas others have observed lower ruminal lactate in dairy cows supplemented with yeast culture (Dias et al., 2018a). The lower acetate coupled with lower lactate was partially explained by $S$. cerevisiae culture's stimulatory growth effect on rumen microbes that metabolize lactate into VFA, such as propionate (Callaway and Martin, 1997; Tun et al., 2020). In the current study, the increase in total VFA in YC cows could be explained by the greater $R$. flavefaciens in $\mathrm{YC}$ cows than $\mathrm{CON}$, a fiber-digesting bacterium that responds to yeast culture supplementation (Zhu et al., 2017). In addition, ruminal $R$. flavefaciens has been reported to require isovalerate (Allison et al., 1962), which might help explain the greater abundance of $R$. flavefaciens in $\mathrm{YC}$ cows because a greater isovalerate was observed in YC cows (Table 4).

The decrease in acetate in $\mathrm{YC}$ cows can partially explain by the lower abundance of Fibrobacter succinogenes in $\mathrm{YC}$ cows, which is an important fiber-digesting bacterium. The F. succinogenes abundance was further described by a parity $\times$ Trt, where lower $F$. succinogenes in YC cows was only observed in primiparous but not multiparous cows (Supplemental Figure S1, https: //doi.org/10.6084/m9.figshare.15145071.v1; Halfen et al., 2021). The lack of a similar parity $\times$ Trt in acetate renders this connection with $F$. succinogenes inconclusive especially when the abundance of other fiber-digesting bacteria such as $E$. ruminantium and $R$. flavefaciens was increased in $\mathrm{YC}$ cows.

\section{Abundance of Ruminal Bacteria}

The positive effects of yeast supplementation on $R$. flavefaciens growth have been documented before (Callaway and Martin, 1997; Mao et al., 2013). Such effects are related to yeast culture growth factors (i.e., organic acids, $\mathrm{B}$ vitamins, and $\mathrm{AA}$ ) that stimulate fiber-digesting bacteria (Callaway and Martin, 1997), thus, benefiting fiber-digesting bacteria such as $R$. flavefaciens. This is in line with results in the current study, where a greater $R$. flavefaciens abundance was observed in the YC group. Additionally, an in vitro study comparing 2 levels of rumen $\mathrm{pH}$ (5.8 vs. 6.5) observed a lower concentration of $R$. flavefaciens at $5.8 \mathrm{pH}$ in comparison to 6.5 (Jiao et al., 2019), confirming prior data suggesting that fiber-degrading bacteria are sensitive to low rumen pH (Chaucheyras-Durand et al., 2008). Then, it is likely that the greater abundance of $R$. flavefaciens in $\mathrm{YC}$ cows was partially driven by a more neutral rumen $\mathrm{pH}$ observed in this group.

The E. ruminantium, a gram-positive bacterium, which also plays a cellulolytic role in the rumen, tended $(P=0.09)$ to be more predominant in YC-fed cows (Table 4). Similar to the present study, a greater relative abundance of E. ruminantium was reported in beef cows classified as most efficient based on low residual feed intake (RFI), and such efficiency was linked to E. ruminantium, improving fiber degradation and feed digestibility (Elolimy et al., 2018a).

The Ruminobacter genus is comprised of the main amylolytic bacteria, including Ruminobacter amylophilus, a gram-negative bacterium, which primarily relies on starch, maltose, and maltodextrins as an energy source (Anderson, 1995). The YC supplementation pro- 
moted a lower proportion of $R$. amylophilus. According to Jiang et al. (2017), the addition of live yeast instead of inactivated yeast to the diet of late lactation dairy cows decreased the relative abundance of Ruminobacter genus, which could at least support the case for a lower abundance of R. amylophilus in YC cows in the current study. Another amylolytic bacteria which abundance was depressed by yeast culture supplementation was Succinimonas amylolytica. This bacterium has been related to SARA conditions in dairy goats, which, along with results on $R$. amylophilus, might help explain the overall greater ruminal $\mathrm{pH}$ observed in $\mathrm{YC}$ cows in the current study. Similar to the current study, others have correlated a lower ruminal abundance of S. amylolytica with feed efficiency in beef cattle (Elolimy et al., 2018a) and dairy cows (Shabat et al., 2016; Elolimy et al., 2018b).

Selenomonas ruminantium has been commonly associated with starch digestion while producing lactic, acetic, and propionic acids (Zhou et al., 2015). This microbial species is a propionate producer through decarboxylation of succinate and utilizes a wide range of substrates, including lactate (Fernando et al., 2010). In a study where they evaluate RFI in dairy cows, they observed that the acrylate pathway that utilizes lactate to propionate was enriched in the low RFI (most efficient) dairy cows (Shabat et al., 2016). Such pathway was further evaluated at the genomic level with lactate-utilizing bacteria, including $A$. lipolytica, $S$. ruminantium, and M. elsdenii. From these, only M. elsdenii presented an enrichment of the acrylate pathway. This indicates that highly efficient dairy cows will rely on $M$. elsdenii to channel propionate production from lactate. In the current study, the higher abundance of M. elsdenii at $30 \mathrm{~d}$ in $\mathrm{YC}$ cows might partially explain the trend for greater feed efficiency in this group in comparison to $\mathrm{CON}$.

Taken together, these data indicate that YC supplementation can positively affect key microbial species related to fiber digestion and lactate-utilizing through the supply of functional metabolites (e.g., AA, peptides, vitamins, and organic acids) and promote essential and consistent conditions such as a more neutral rumen $\mathrm{pH}$.

\section{CONCLUSIONS}

The findings observed in this study suggested that YC supplementation improves the rumen environment by promoting a more neutral rumen $\mathrm{pH}$ and increasing total VFA and decreasing ruminal acetate. Additionally, our results suggest that feeding $\mathrm{YC}$ enhanced specific ruminal bacteria populations, including lactate-utilizers (i.e., M. elsdenii) and fiber digesters (i.e., E. ruminantium and Ruminococcus flavefaciens). The lower abundance of amylolytic bacteria in YC cows, including Ruminobacter amylophylus and Succinimonas amylolytica, could partially explain the ruminal lower $\mathrm{pH}$ in $\mathrm{YC}$ cows. In contrast to CON cows, $\mathrm{YC}$ cows had lower EB, which could be partly described by the trend for lower DMI as \% of BW. Overall, the changes in ruminal bacteria species evaluated in this study by yeast culture supplementation seem to promote specific fiber-digesting and lactate-utilizing bacteria while decreasing amylolytic bacteria, which might have partially promoted more neutral rumen $\mathrm{pH}$, greater total VFA, and isovalerate. A more powerful study with multiple diurnal rumen collections would be required to clearly demonstrate the level of improvement on these rumen parameters and ruminal bacteria populations.

\section{ACKNOWLEDGMENTS}

The authors gratefully acknowledge Phibro Animal Health Corporation (Teaneck, NJ) for partial financial support of this research. The authors thank Peter Linke and Danielle Tews of the Dairy Research and Training Facility (South Dakota State University, Brookings) staff for help with animal management. J. D. Chapman and E. D. Sharman are employees of Phibro Animal Health Corporation, which had a role in the study design and provided financial support to cover costs of animal use, data collection, and sample analysis. The authors have not stated any other conflicts of interest.

\section{REFERENCES}

AAFCO. 2020. Official Publication. Association of American Feed Control Officials.

Abdela, N. 2016. Sub-acute ruminal acidosis (SARA) and its consequence in dairy cattle: A review of past and recent research at global prospective. Achiev. Life Sci. 10:187-196. https://doi.org/ 10.1016/j.als.2016.11.006.

Abdelmegeid, M. K., A. A. Elolimy, Z. Zhou, V. Lopreiato, J. C. McCann, and J. J. Loor. 2018. Rumen-protected methionine during the peripartal period in dairy cows and its effects on abundance of major species of ruminal bacteria. J. Anim. Sci. Biotechnol. 9:17. https://doi.org/10.1186/s40104-018-0230-8.

Acharya, S., J. P. Pretz, I. Yoon, M. F. Scott, and D. P. Casper. 2017. Effects of Saccharomyces cerevisiae fermentation products on the lactational performance of mid-lactation dairy cows. Transl. Anim. Sci. 1:221-228. https://doi.org/10.2527/tas2017.0028.

Allison, M. J., M. P. Bryant, and R. N. Doetsch. 1962. Studies on the metabolic function of branched-chain volatile fatty acids, growth factors for ruminococci. I. Incorporation of isovalerate into leucine. J. Bacteriol. 83:523-532. https://doi.org/10.1128/jb.83.3.523-532 .1962 .

Alshaikh, M. A., M. Y. Alsiadi, S. M. Zahran, H. H. Mogawer, and T. A. Aalshowime. 2002. Effect of feeding yeast culture from different sources on the performance of lactating Holstein cows in Saudi Arabia. Asian-Australas. J. Anim. Sci. 15:352-356. https:// doi.org/10.5713/ajas.2002.352.

Alugongo, G. M., J. Xiao, Z. Wu, S. Li, Y. Wang, and Z. Cao. 2017. Review: Utilization of yeast of Saccharomyces cerevisiae origin in artificially raised calves. J. Anim. Sci. Biotechnol. 8:34. https://doi .org/10.1186/s40104-017-0165-5. 
Ambriz-Vilchis, V., N. S. Jessop, R. H. Fawcett, M. Webster, D. J. Shaw, N. Walker, and A. I. Macrae. 2017. Effect of yeast supplementation on performance, rumination time, and rumen $\mathrm{pH}$ of dairy cows in commercial farm environments. J. Dairy Sci. 100:5449-5461. https://doi.org/10.3168/jds.2016-12346.

Anderson, K. L. 1995. Biochemical analysis of starch degradation by Ruminobacter amylophilus 70. Appl. Environ. Microbiol. 61:14881491. https://doi.org/10.1128/aem.61.4.1488-1491.1995.

Bach, A., C. Iglesias, and M. Devant. 2007. Daily rumen pH pattern of loose-housed dairy cattle as affected by feeding pattern and live yeast supplementation. Anim. Feed Sci. Technol. 136:146-153. https://doi.org/10.1016/j.anifeedsci.2006.09.011.

Bergen, W. G., and D. B. Bates. 1984. Ionophores: Their effect on production efficiency and mode of action. J. Anim. Sci. 58:1465-1483. https://doi.org/10.2527/jas1984.5861465x.

Callaway, E. S., and S. A. Martin. 1997. Effects of a Saccharomyces cerevisiae culture on ruminal bacteria that utilize lactate and digest cellulose. J. Dairy Sci. 80:2035-2044. https://doi.org/10 $.3168 /$ jds.S0022-0302(97)76148-4.

Chaney, A. L., and E. P. Marbach. 1962. Modified reagents for determination of urea and ammonia. Clin. Chem. 8:130-132. https:// doi.org/10.1093/clinchem/8.2.130.

Chaucheyras-Durand, F., N. D. Walker, and A. Bach. 2008. Effects of active dry yeasts on the rumen microbial ecosystem: Past, present and future. Anim. Feed Sci. Technol. 145:5-26. https://doi.org/10 .1016/j.anifeedsci.2007.04.019.

Colmenero, J. J. O., and G. A. Broderick. 2006. Effect of dietary crude protein concentration on milk production and nitrogen utilization in lactating dairy cows. J. Dairy Sci. 89:1704-1712. https://doi .org/10.3168/jds.S0022-0302(06)72238-X.

Dias, A. L. G., J. A. Freitas, B. Micai, R. A. Azevedo, L. F. Greco, and J. E. P. Santos. 2018a. Effect of supplemental yeast culture and dietary starch content on rumen fermentation and digestion in dairy cows. J. Dairy Sci. 101:201-221. https://doi.org/10.3168/ jds.2017-13241.

Dias, J. D. L., R. B. Silva, T. Fernandes, E. F. Barbosa, L. E. C. Graças, R. C. Araujo, R. A. N. Pereira, and M. N. Pereira. 2018b. Yeast culture increased plasma niacin concentration, evaporative heat loss, and feed efficiency of dairy cows in a hot environment. J. Dairy Sci. 101:5924-5936. https://doi.org/10.3168/jds.2017-14315.

Elghandour, M. M. Y., A. Khusro, M. J. Adegbeye, Z. Tan, S. H. Abu Hafsa, R. Greiner, E. A. Ugbogu, U. Y. Anele, and A. Z. M. Salem. 2020. Dynamic role of single-celled fungi in ruminal microbial ecology and activities. J. Appl. Microbiol. 128:950-965. https:// doi.org/10.1111/jam.14427.

Elolimy, A. A., M. K. Abdelmegeid, J. C. McCann, D. W. Shike, and J. J. Loor. 2018a. Residual feed intake in beef cattle and its association with carcass traits, ruminal solid-fraction bacteria, and epithelium gene expression. J. Anim. Sci. Biotechnol. 9:67. https:/ /doi.org/10.1186/s40104-018-0283-8.

Elolimy, A. A., J. M. Arroyo, F. Batistel, M. A. Iakiviak, and J. J. Loor. 2018b. Association of residual feed intake with abundance of ruminal bacteria and biopolymer hydrolyzing enzyme activities during the peripartal period and early lactation in Holstein dairy cows. J. Anim. Sci. Biotechnol. 9:43. https://doi.org/10.1186/ s40104-018-0258-9.

Enemark, J. M. 2008. The monitoring, prevention and treatment of sub-acute ruminal acidosis (SARA): A review. Vet. J. 176:32-43. https://doi.org/10.1016/j.tvjl.2007.12.021.

Erasmus, L. J., P. H. Robinson, A. Ahmadi, R. Hinders, and J. E. Garrett. 2005. Influence of prepartum and postpartum supplementation of a yeast culture and monensin, or both, on ruminal fermentation and performance of multiparous dairy cows. Anim. Feed Sci. Technol. 122:219-239. https://doi.org/10.1016/j.anifeedsci 2005.03.004

Fernando, S. C., H. T. Purvis 2nd, F. Z. Najar, L. O. Sukharnikov, C. R. Krehbiel, T. G. Nagaraja, B. A. Roe, and U. Desilva. 2010. Rumen microbial population dynamics during adaptation to a high-grain diet. Appl. Environ. Microbiol. 76:7482-7490. https:// doi.org/10.1128/AEM.00388-10.
Ferreira, G., E. S. Richardson, C. L. Teets, and V. Akay. 2019. Production performance and nutrient digestibility of lactating dairy cows fed low-forage diets with and without the addition of a live-yeast supplement. J. Dairy Sci. 102:6174-6179. https://doi.org/10.3168/ jds.2019-16396.

Ghazanfar, S., N. Khalid, I. Ahmed, and M. Imran. 2017. Probiotic yeast: Mode of action and its effects on ruminant nutrition. Pages 180-202 in Yeast - Industrial Applications. A. Morata and I. Loira, ed. InTech.

Grazziotin, R. C. B., J. Halfen, F. Rosa, E. Schmitt, J. L. Anderson, V. Ballard, and J. S. Osorio. 2020. Altered rumen fermentation patterns in lactating dairy cows supplemented with phytochemicals improve milk production and efficiency. J. Dairy Sci. 103:301312. https://doi.org/10.3168/jds.2019-16996.

Halfen, J., N. A. Carpinelli, F. A. B. D. Pino, J. Chapman, E. Sharman, and J. Anderson. 2021. Effects of yeast culture supplementation on lactation performance and rumen fermentation profile and microbial abundance in mid-lactation Holstein dairy cows. figshare. Journal contribution. https://doi.org/https://doi.org/10 .6084/m9.figshare.15145071.v1.

Henderson, G., F. Cox, S. Kittelmann, V. H. Miri, M. Zethof, S. J. Noel, G. C. Waghorn, and P. H. Janssen. 2013. Effect of DNA extraction methods and sampling techniques on the apparent structure of cow and sheep rumen microbial communities. PLoS One 8:e74787. https://doi.org/10.1371/journal.pone.0074787.

Hristov, A. N., G. Varga, T. Cassidy, M. Long, K. Heyler, S. K. Karnati, B. Corl, C. J. Hovde, and I. Yoon. 2010. Effect of Saccharomyces cerevisiae fermentation product on ruminal fermentation and nutrient utilization in dairy cows. J. Dairy Sci. 93:682-692. https://doi.org/10.3168/jds.2009-2379.

Jami, E., B. A. White, and I. Mizrahi. 2014. Potential role of the bovine rumen microbiome in modulating milk composition and feed efficiency. PLoS One 9:e85423. https://doi.org/10.1371/journal .pone.0085423.

Jiang, Y., I. M. Ogunade, S. Qi, T. J. Hackmann, C. R. Staples, and A. T. Adesogan. 2017. Effects of the dose and viability of Saccharomyces cerevisiae. 1. Diversity of ruminal microbes as analyzed by Illumina MiSeq sequencing and quantitative PCR. J. Dairy Sci. 100:325-342. https://doi.org/10.3168/jds.2016-11263.

Jiao, P., C. Wei, Y. Sun, X. Xie, Y. Zhang, S. Wang, G. Hu, O. AlZahal, and W. Yang. 2019. Screening of live yeast and yeast derivatives for their impact of strain and dose on in vitro ruminal fermentation and microbial profiles with varying media $\mathrm{pH}$ levels in high-forage beef cattle diet. J. Sci. Food Agric. 99:6751-6760. https://doi.org/10.1002/jsfa.9957.

Leicester, H. C., P. H. Robinson, and L. J. Erasmus. 2016. Effects of two yeast based direct fed microbials on performance of high producing dairy cows. Anim. Feed Sci. Technol. 215:58-72. https:// doi.org/10.1016/j.anifeedsci.2016.03.003.

Li, S., I. Yoon, M. Scott, E. Khafipour, and J. C. Plaizier. 2016. Impact of Saccharomyces cerevisiae fermentation product and subacute ruminal acidosis on production, inflammation, and fermentation in the rumen and hindgut of dairy cows. Anim. Feed Sci. Technol. 211:50-60. https://doi.org/10.1016/j.anifeedsci.2015.10.010.

Mao, H. L., H. L. Mao, J. K. Wang, J. X. Liu, and I. Yoon. 2013. Effects of Saccharomyces cerevisiae fermentation product on in vitro fermentation and microbial communities of low-quality forages and mixed diets. J. Anim. Sci. 91:3291-3298. https://doi.org/10.2527/ jas.2012-5851.

Miller-Webster, T., W. H. Hoover, M. Holt, and J. E. Nocek. 2002. Influence of yeast culture on ruminal microbial metabolism in continuous culture. J. Dairy Sci. 85:2009-2014. https://doi.org/10 .3168/jds.S0022-0302(02)74277-X.

Mullins, C. R., L. K. Mamedova, A. J. Carpenter, Y. Ying, M. S. Allen, I. Yoon, and B. J. Bradford. 2013. Analysis of rumen microbial populations in lactating dairy cattle fed diets varying in carbohydrate profiles and Saccharomyces cerevisiae fermentation product. J. Dairy Sci. 96:5872-5881. https://doi.org/10.3168/jds .2013-6775.

Newbold, C. J., R. J. Wallace, X. B. Chen, and F. M. McIntosh. 1995. Different strains of Saccharomyces cerevisiae differ in their effects 
on ruminal bacterial numbers in vitro and in sheep. J. Anim. Sci. 73:1811-1818. https://doi.org/10.2527/1995.7361811x.

NRC (National Research Council). 2001. Nutrient Requirements of Dairy Cattle. Vol. 7th. Natl. Acad. Press.

Oeztuerk, H. 2009. Effects of live and autoclaved yeast cultures on ruminal fermentation in vitro. J. Anim. Feed Sci. 18:142-150. https: //doi.org/10.22358/jafs/66378/2009.

Opsi, F., R. Fortina, S. Tassone, R. Bodas, and S. López. 2012. Effects of inactivated and live cells of Saccharomyces cerevisiae on in vitro ruminal fermentation of diets with different forage: concentrate ratio. J. Agric. Sci. 150:271-283. https://doi.org/10 $.1017 /$ S0021859611000578.

Ospina, P. A., J. A. McArt, T. R. Overton, T. Stokol, and D. V. Nydam. 2013. Using nonesterified fatty acids and beta-hydroxybutyrate concentrations during the transition period for herd-level monitoring of increased risk of disease and decreased reproductive and milking performance. Vet. Clin. North Am. Food Anim. Pract. 29:387-412. https://doi.org/10.1016/j.cvfa.2013.04.003.

Plaizier, J. C. 2004. Replacing chopped alfalfa hay with alfalfa silage in barley grain and alfalfa-based total mixed rations for lactating dairy cows. J. Dairy Sci. 87:2495-2505. https://doi.org/10.3168/ jds.S0022-0302(04)73374-3.

Poppy, G. D., A. R. Rabiee, I. J. Lean, W. K. Sanchez, K. L. Dorton, and P. S. Morley. 2012. A meta-analysis of the effects of feeding yeast culture produced by anaerobic fermentation of Saccharomyces cerevisiae on milk production of lactating dairy cows. J. Dairy Sci. 95:6027-6041. https://doi.org/10.3168/jds.2012-5577.

Raun, N. S., and W. Burroughs. 1962. Suction strainer technique in obtaining rumen fluid samples from Intact Lambs. J. Anim. Sci. 21:454-457. https://doi.org/10.2527/jas1962.213454x.

Schingoethe, D. J., K. N. Linke, K. F. Kalscheur, A. R. Hippen, D. R. Rennich, and I. Yoon. 2004. Feed efficiency of mid-lactation dairy cows fed yeast culture during summer. J. Dairy Sci. 87:4178-4181. https://doi.org/10.3168/jds.S0022-0302(04)73561-4.

Shabat, S. K., G. Sasson, A. Doron-Faigenboim, T. Durman, S. Yaacoby, M. E. Berg Miller, B. A. White, N. Shterzer, and I. Mizrahi. 2016. Specific microbiome-dependent mechanisms underlie the energy harvest efficiency of ruminants. ISME J. 10:2958-2972. https: //doi.org/10.1038/ismej.2016.62.

Shi, W., C. E. Knoblock, K. V. Murphy, T. C. Bruinjé, I. Yoon, D. J. Ambrose, and M. Oba. 2019. Effects of supplementing a Saccharomyces cerevisiae fermentation product during the periparturient period on performance of dairy cows fed fresh diets differing in starch content. J. Dairy Sci. 102:3082-3096. https://doi.org/10 $.3168 /$ jds.2018-15307.
Shurson, G. C. 2018. Yeast and yeast derivatives in feed additives and ingredients: Sources, characteristics, animal responses, and quantification methods. Anim. Feed Sci. Technol. 235:60-76. https://doi .org/10.1016/j.anifeedsci.2017.11.010.

Tun, H. M., S. Li, I. Yoon, S. J. Meale, P. A. Azevedo, E. Khafipour, and J. C. Plaizier. 2020. Saccharomyces cerevisiae fermentation products (SCFP) stabilize the ruminal microbiota of lactating dairy cows during periods of a depressed rumen $\mathrm{pH}$. BMC Vet. Res. 16:237. https://doi.org/10.1186/s12917-020-02437-w.

Tyrrell, H. F., and J. T. Reid. 1965. Prediction of the energy value of cow's milk. J. Dairy Sci. 48:1215-1223. https://doi.org/10.3168/ jds.S0022-0302(65)88430-2.

Van Amburgh, M. E., E. A. Collao-Saenz, R. J. Higgs, D. A. Ross, E. B. Recktenwald, E. Raffrenato, L. E. Chase, T. R. Overton, J. K. Mills, and A. Foskolos. 2015. The Cornell Net Carbohydrate and Protein System: Updates to the model and evaluation of version 6.5. J. Dairy Sci. 98:6361-6380. https://doi.org/10.3168/jds.2015 $-9378$.

Wildman, E. E., G. M. Jones, P. E. Wagner, R. L. Boman, H. F. Troutt Jr., and T. N. Lesch. 1982. A dairy-cow body condition scoring system and its relationship to selected production characteristics. J. Dairy Sci. 65:495-501. https://doi.org/10.3168/jds .S0022-0302(82)82223-6.

Zhou, M., Y. Chen, and L. L. Guan. 2015. Rumen bacteria. Pages 79-95 in Rumen Microbiology: From Evolution to Revolution. A. Puniya, R. Singh, and D. Kamra, ed. Springer.

Zhu, W.. Z. Wei, N. Xu, F. Yang, I. Yoon, Y. Chung, J. Liu, and J. Wang. 2017. Effects of Saccharomyces cerevisiae fermentation products on performance and rumen fermentation and microbiota in dairy cows fed a diet containing low quality forage. J. Anim. Sci. Biotechnol. 8:36. https://doi.org/10.1186/s40104-017-0167-3.

\section{ORCIDS}

J. Halfen () https://orcid.org/0000-0002-1317-1322

N. Carpinelli ๑ https://orcid.org/0000-0003-1208-8671

F. A. B. Del Pino $\odot$ https://orcid.org/0000-0002-5142-5215

J. D. Chapman (1 https://orcid.org/0000-0002-3412-6432

E. D. Sharman $\odot$ https://orcid.org/0000-0002-5776-5819

J. L. Anderson $\odot$ https://orcid.org/0000-0001-7590-0749

J. S. Osorio @ https://orcid.org/0000-0001-6192-0917 